\title{
Editorial
}

\section{The Intellectual Challenge Facing Contemporary Islamic Scholarship}

Language, perhaps the most mysterious element of human existence, enables us to acquire some insight into the human spirit. When used as an instrument for expressing ideas and sharing feelings, it helps externalize individual consciousness and makes it accessible to others. But it is also an instrument for shaping individual consciousness by means of internalizing notions and ideas shaped by others. Human consciousness, both individual and collective, thus presupposes language.

Language and discourse are essential for any collective action. While such individual actions as hunting for food or constructing a dwelling may arguably be possible without these abilities, collective action requires the development of shared meaning and common understanding through linguistic discourse. The greater the collectivity and the more profound and far-reaching the collective enterprise is, the more universal and abstract the language becomes. Thus religion and philosophy have always been central to human civilization.

Yet despite the proximity between words and concepts, or language and discourse, the two are far from identical. Although words denote concepts and a discourse consists of linguistic terms, the meaning embedded in words and terms is ultimately determined by social experiences and psychological states. Hence, in different social milieu and sociohistorical contexts, what some consider as "courage" might be regarded by others as "insanity," and what one generation might regard as "prudence" may denote "cowardice" in another. Evidently, meaning lies not in individual words but in conceptual frameworks and historically situated discourses.

Take, for instance, such concepts as freedom, equality, dignity, or tolerance. These concepts often struck a cord among people of different cultures and ideological persuasions. But whether these words have a positive impact on people hinges not merely on their abstract meaning, but on how 
they are concretized and contextualized in a specific time and place. That is, their ability to enrich human life hinges on the specific sociopolitical models and practical arrangements they inspire.

This line of thought leads us directly to the main challenge facing Islamic scholarship today. While many Muslim scholars have embraced the values of equality, freedom, tolerance, and the rule of law identified today with liberal democracy, I contend that Islam's contribution to humanity's future lies not in a simplistic embrace or advancement of these abstract concepts. Rather, it lies in giving them concrete expression and providing operational models to help modern society overcome the recent sociopolitical trends threatening to undermine the meaning of human dignity and destabilize social order. Contemporary Islamic scholarship must relate abstract moral values to individual consciousness and a community's collective experience.

\section{Decoupling the Secular and the Religious}

In ancient times, the secular and religious worlds were kept apart and thus operated under markedly different rules. The secular world adhered to the paradigm of power, in which domination and control are intrinsic values and effectiveness served as an overarching criterion. The most eloquent expression of the purely secular rationale was captured in Machiavelli's The Prince. "The end justifies the means" was the guiding principle of the secular world.

The religious world was a world of sheer spirituality and utter goodness, one completely divorced from the secular world. Religious people were expected to eschew and shun secular injustice and corruption, avoid politics and remain aloof from the state, instead of confronting and overcoming such developments. The uneasy coexistence of the secular and religious, and their utter separation, is best captured in St. Augustine's The City of God. As one reads his attempt to isolate the "city of man" from the "city of God," one is compelled to conclude that the two can never intersect, and that the latter can only be experienced in a heavenly, rather than an earthly, mode of existence.

These two worlds were brought into a remarkable harmony for the first time under the principles of Islam. It was in the state of Medina that we first encounter a clear example of a polity where universally proclaimed moral values formed the criteria of political judgment. Political leaders and statesmen were expected to recognize not only the value of efficiency, but also the values of justice, dignity, equality, and freedom. This important transformation was observed by Hegel (1770-1831), a leading European philo- 
sopher of history. In his Philosophy of History [New York: Dove Publications, 1956], Hegel recognized that the unity between the secular and spiritual took place in Islamic society and civilization long before it did so in the modern West:

We must therefore regard [the reconciliation between the secular and spiritual] as commencing rather in the enormous contrast between the spiritual, religious principles, and the barbarian Real World. For spirit as the consciousness of an inner world is, at the commencement, itself still in an abstract form. All that is secular is consequently given over to rudeness and capricious violence. The Mohammedan principle, the enlightenment of the oriental world, is the first to contravene this barbarism and caprice. We find it developing itself later and more rapidly than Christianity; for the latter needed eight centuries to grow up into a political form. ${ }^{1}$

The modern West followed the example of the historical Islamic world in demanding that holders of political power operate under a set of moral rules. But as the modern West harmonized the secular and religious only nationally, the international realm was free to operate under the dynamics of power politics and secular rudeness. This failure was a source for the senseless violence that claimed well over 100 million war victims in the twentieth century, including over 80 million in two world wars. Recognizing the danger of keeping international politics under a purely secular evaluation, the United States led the effort that culminated in formalizing international law and creating the United Nations after World War II. Yet this effort was effectively undermined and compromised by political realists who enjoyed a disproportionate sway over American foreign policy and who were always ready to justify American violations of international covenants and treaties in the name of national security.

Ironically, contemporary Muslim societies have exceeded all others in decoupling the secular and the religious and now find themselves entangled in a crisis of legitimacy. Many Muslim regimes operate outside the realm of moral correctness and follow only to the logic of power politics. Even more alarming is that this decoupling has reached deep into religiously inspired movements, which seem to succumb to the logic of power and are ready to employ amoral - even immoral - strategies in their fight against political corruption and oppression.

The decoupling of the secular and religio-moral spheres and the rise of political rudeness in western democracy should be a source of concern. The strengthening of ultra-nationalist sentiments in Austria, Germany, and most recently in France, and the return of religious and ethnic profiling in the 
United States in the wake of September 11, are quite disturbing trends and point to a process of secular-moral decoupling.

It is worth noting that this process advances despite the religious reassertion occurring throughout the world. This is because the coupling and decoupling of the secular and the religious must be judged by whether or not moral values limit individual and collective behavior, and whether a profound commitment to moral principles restrain the political actions of social groups and group leaders. An exclusivist religious community that permits rudeness and capricious violence outside ethnic and religious bonds can be as brutal as - or even more brutal than - groups purely defined on the basis of secular criteria.

\section{Advance Rationalization and the Loss of Freedom}

Modern society is the result of a systematic restructuring and reordering of society in accordance with a set of core values that define modern life. Max Weber (1864-1920), the eminent German sociologist, called this process rationalization. Although he admired this process, Weber was disturbed by its tendency to shrink the area of individual liberty and thereby cause a progressive loss of freedom. This loss, he observed, is the outcome of rationalization, which takes the form of bureaucratic control. Although he considered bureaucracy to be the cornerstone of capitalist civilization and claimed that it brought a superior form of organization to society, he noted that it simultaneously transforms society into an enormous human machine in which everyone has to fit into a socially predetermined niche and perform a socially predesigned role. Clearly, this mechanical environment engenders a tremendously increased efficiency but also undermines individual freedom and turns society into an "iron cage."

The overpowering modern state - the leviathan preached by Thomas Hobbes at the dawn of the Enlightenment but rejected by liberal democrats is being reinvented by the neo-Hobbsians of the twenty-first century. This leviathan, which ensures security at the expense of individual freedom, already controls most developing countries and seems to be creeping slowly into western democracies. The brutal September 11 attack on the United States, as well as other events, have underscored the vulnerability of American democracy to extreme restrictions on political freedom in the name of security. The passage of the Patriot Act by the US Congress in late 2001, despite the pervasive presence of provisions that undermine fundamental freedoms, displays the modern state's propensity to acquire unbridled power. ${ }^{2}$ 
Central to this process of power accumulation is the modern state's ability to use law as a tool of power aggrandizement to extend its control over civil society and regulate every facet of individual and collective life. Taking that power, or limiting it markedly, is the only way to prevent the modern state from turning into a leviathan. It is also the only way to prevent the use of Islamic law (the Shari ah) as an instrument of persecution and control. It is an irony of history that the Shari ah, which historically strove to limit the state's power, is being now used to make the state overpowering. This irony has its roots in the modern conception of state. For many Islamic reformers, an important landmark of reasserting Islamic values and identity is that Islamic law should become state law. Those who insist on marrying the state with the Shari ah are completely unaware of the fact that legislation in historical Islam was a function of civil society rather than of the state.

Lawrence Rosen gives us an insight into this important fact in his Anthropology of Justice: Law as Culture in Islamic Society. While his work focuses on a Shari ah court in a small Moroccan town, it provides a wealth of information about the paradigm that guided the Islamic legal system in historical Muslim society. "[I]n the classical Islamic theory of state," he remarks,

law and government were kept largely separate form one another. The state was seen not as an instrument for the application of law, nor were the courts, either through religious doctrine or a concept of the social good, envisioned as vehicles for economic redistribution or the construction of a particular political order. It was the duty of the political authorities to enforce the claims of God - even by maintaining their own courts for the punishment of specific crimes - but beyond that they were to insure that men could carry forth their own affairs without governmental interference. ${ }^{3}$

Rosen's work shed light on another fact concerning the relationship of law and state in historical Islam, a fact often missed by both the advocates and opponents of an Islamically inspired state: In historical Islamic society, down to the Ottoman Empire, the community was the locus of law and morality. Judges were expected to enforce local norms and follow locally accepted interpretations of normative texts, not to superimpose on the community an abstract doctrine articulated by non-local or distant individuals. "[I]n Islamic law," he points out,

the [legal] concepts are measured against those cultural principles that allow people to return to the negotiation of their own arrangement. Its regularity is vertical, not horizontal: it seeks consistency with common-sense 
assumptions about humanity, not through the refinement of categories of its own creation. Islamic law is a system of adjudication, of ethics, and of logic that finds its touchstone not in the perfecting of doctrine but in the standards of everyday life, and measured in this way it is enormously developed, integrated, logical, and successful. ${ }^{4}$

As a legal anthropologist, Rosen was more aware of how Islamic law functioned on the societal level than among jurists. It seems he was not aware of the enormously elaborate and abstract science of Islamic jurisprudence. This fact should, of course, make us more intrigued by historical Muslim society's ability to control legislation and adjudication, and to keep statesmen and jurists in check. Further, this fact speaks volumes about the vibrancy of civil society in historical Islam and should inspire contemporary scholars to reconsider the relationship between state and law. More specifically, I submit that the relationship among state, law, and society in historical Islam provides us with a cue for overcoming the "iron cage" of advanced modern society.

This vital task requires forward thinking and a creative synthesis of the modern and the authentic. And therein lies the enormous challenge facing contemporary Islamic thought.

Louay M. Safi

\section{Notes}

1. Georg W. H. Hegel, Philosophy of History (New York: Dove Publications, 1956), 109.

2. For an excellent commentary of the Patriot Act, see Nancy Chang, Silencing Political Dissent: How the USA Patriot Act Undermines the Constitution (New York: Center for Constitutional Rights, 2002).

3. Lawrence Rosen, Anthropology of Justice: Law as Culture in Islamic Society (Massachusetts: Cambridge University Press, 1998), 61.

4. Ibid., 56 . 